\title{
Alberto Caruso*
}

\section{The Master, \\ l’opera lirica basata sull'omonimo romanzo di Colm Tóibín, musica di Alberto Caruso, libretto di Colm Tóibín}

DOI: http://dx.doi.org/10.12775/LC.2017.026

\begin{abstract}
"There is no greater work of art than a great portrait."1 ["Non c'è più grande opera d'arte di un grande ritratto."]
\end{abstract}

omponendo un'opera lirica su Henry James (1843-1916), ho realizzato il mio sogno di creare un ritratto in musica del grande scrittore. Tra tutte le mie letture su James, il premiato romanzo del 2004 The Master dello scrittore irlandese Colm Tóibín, è un capolavoro unico: si appropria delle parole dello scrittore, delle sue lettere, del suo stile, afferra la sostanza della vita di James nella sua complessità, ambiguità, segretezza, "hiding, revealing, hiding, revealing", ["nascondendo, rivelando, nascondendo, rivelando"], costruendo il dettaglio, senza fare criticismo letterario.

Ne ho visto immediatamente un ideale libretto d'opera. Così ho deciso di scrivere a Tóibín per chiedergli cosa ne pensasse; ci siamo incontrati a New York e alla mia proposta ha risposto con entusiasmo cominciando subito a scrivere il suo primo libretto d'opera. Da quel momento è iniziato il nostro sodalizio.

\footnotetext{
* Compositore, direttore d'orchestra e pianista, si è esibito in importanti festival e teatri in Europa, Stati Uniti, Messico, Giappone e Australia. Ha composto opere liriche, musica sacra, colonne sonore per cinema, televisione e teatro. Sta ora componendo la sua terza opera lirica.

1 H. James, "John S. Sargent", Harper's New Monthly Magazine Vol. LXXV (June to November, 1887), Harper and Brothers, New York 1887, p. 691.

2 C. Tóibín in una intervista con F. O’Toole, in Reading Colm Tóibín, ed. P. Delaney, The Liffey Press, Dublin, 2008, p. 197.
} 
Per due estati l'ho raggiunto nel suo eremo sui Pirenei catalani, dove, appena Colm aveva pronta una nuova scena, me la declamava: la sua lettura era teatrale, musicale, fraseggiata e ritmata, con colori e toni diversi per ogni personaggio a cui dava vita. La mia musica sgorgava copiosa, ispirato come ero dalla sua voce ipnotica e dal suo talento di declamatore che venivo a scoprire. Perché Tóibín è poeta, prima di diventare romanziere e profondo conoscitore della musica. "James is my character and I want him haunted, uneasy but charming" . ["James è il mio personaggio e lo voglio ossessionato, inquieto ma affascinante"].

Accanto alle nostre sessioni in Spagna, ho potuto lavorare alla composizione di The Master nella solitudine di due importanti ritiri: il primo al Tyrone Guthrie Centre ad Annaghmakerrig in Irlanda, "The alienated island", ["L'isola alienata”], come la definisce lo stesso James; e in Italia, a Bogliasco, Genova, con una fellowship della Bogliasco Foundation di New York.

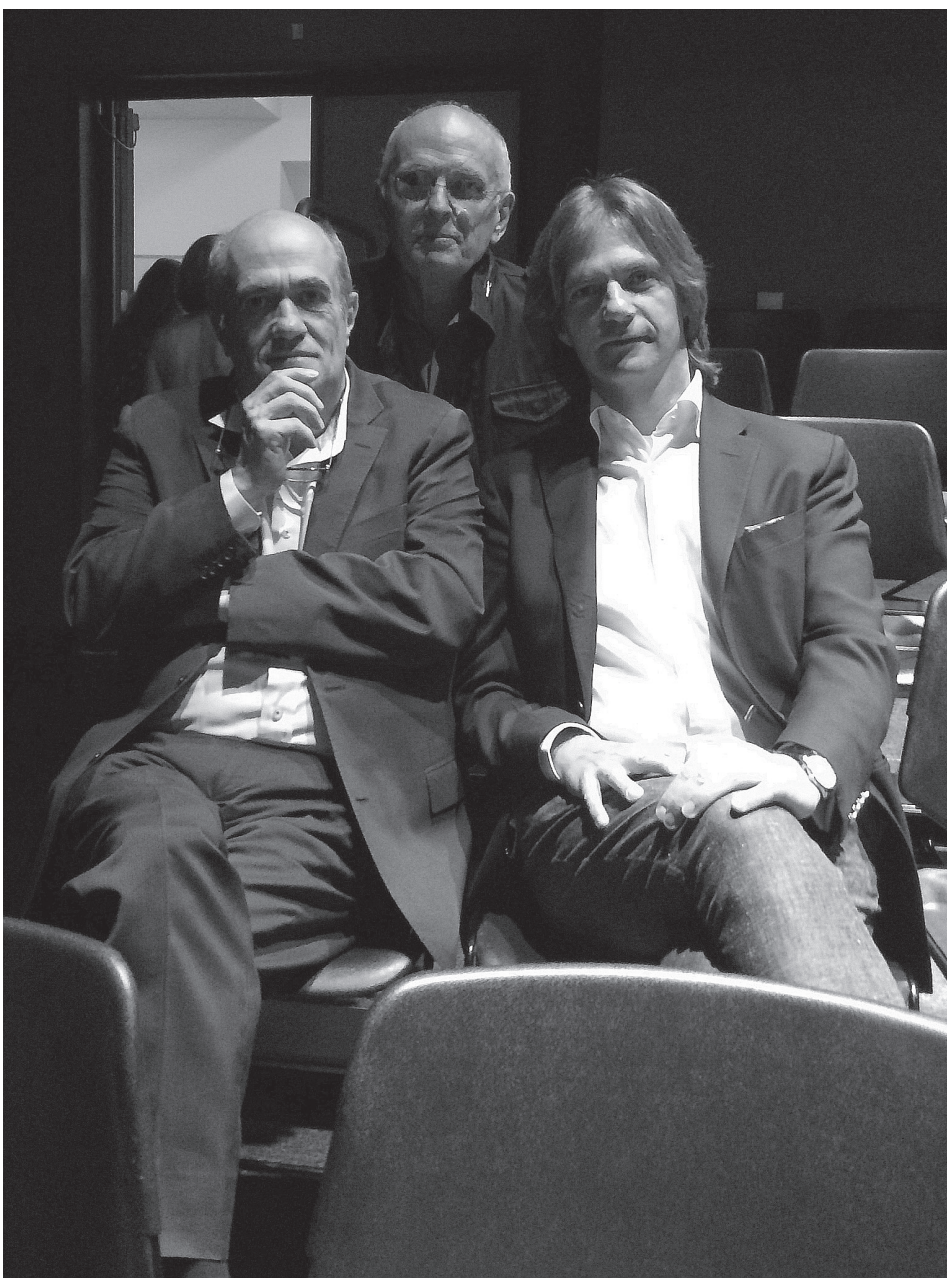

Colm Tóibín, Ron Daniels, Alberto Caruso. From the author's private collection

\footnotetext{
3 Idem, "A More Elaborate Web: Becoming Henry James", The Henry James Review Vol. 30 N. 3 (Fall 2009), p. 231.
} 
Nel libretto, Tóibín inserisce scene nuove rispetto al romanzo, sviluppando in particolare il ruolo della scrittrice americana Constance Fenimore Woolson (1840-1894), la sua migliore amica. Spettatrice, co-protagonista, confidente, alter-ego e coscienza di Henry stesso, il fantasma di Constance accompagna il Maestro nei ricordi e nell'azione sul palcoscenico, in flashback dove gli spettri del passato rivivono come personaggi riaffiorati dalle sue opere. "He is a great mystery. As an artist, he played with ideas of secrecy with the possibility always of dramatic discovery [...] Our interest in his private life is both prurient and pure" . ["Egli è un grande mistero. Come artista, ha giocato con idee di segretezza con la possibilità sempre di drammatica scoperta $[. .$.$] Il nostro interesse per la sua vita privata$ è insieme pruriginoso e puro"].

L'opera The Master ha la sua prima casa alla University of Colorado a Boulder, per un workshop di un mese con tre rappresentazioni finali il 13, 14 e 15 giugno 2014, con la regia di Ron Daniels, regista associato onorario della Royal Shakespeare Company.

Il trio Tóibín-Caruso-Daniels è così costituito per dare vita ai personaggi che sino a quel momento esistevano in partitura e nel libretto. Un work in progress tra di noi e con il cast in perfetta intesa ad aggiungere, sottrarre, modificare, sviluppare, alla ricerca della perfezione, "detail after detail", ["dettaglio dopo dettaglio"], come ama dire Tóibín, forgiando l'opera in divenire. Mentre io continuavo a elaborare la partitura e preparavo i cantanti, Ron definiva interpretazione, movimenti, scene e costumi, e Colm, nel partecipare alle prove, ascoltando il suo libretto nella mia musica, traeva ispirazione per nuovi versi.

Colm scriveva ovunque, nelle nostre visite sulle montagne rocciose, nell'hotel del film Shining di Stanley Kubrick, nei caffè di Boulder. Le prime ore della mattina erano quelle per ciascuno di noi dedicate al lavoro in solitudine, tutto il resto della giornata era l'occasione per scambiare idee, pensieri, per definire i nostri progetti, elaborarli, condividerli.

Tóibín, nel romanzo come nel libretto, sceglie gli anni tra il 1895 e il 1899 nella vita di James.

For me, as a novelist attempting to dramatize James's life, the five years between his failure in the theater in 1895 and his beginning to work on the three great novels, The Wings of The Dove, The Ambassadors and The Golden Bowl, seemed the richest years of his life. It was a time when he looked failure straight in the eye and did not blink, but a time also when he was haunted by the deaths of his parents and his sister Alice. His moving to Lamb House in these years rescued him, offered him a haven, and, in turn, offered me, trying to imagine him, inspirations.

[Per me, come romanziere che si cimenta nella drammatizzazione della vita di James, i cinque anni fra il suo fallimento nel teatro nel 1895 e l'inizio del lavoro sui tre grandi romanzi, The Wings of The Dove, The Ambassadors e The Golden Bowl, mi sono sembrati gli anni più ricchi della sua vita. Fu un tempo in cui guardava il fallimento fisso negli occhi senza batter ciglio, ma anche un tempo in cui era ossessionato dalla morte dei suoi genitori e di sua sorella Alice. Il suo trasferirsi alla Lamb House in quegli anni lo salvò, offrendogli un rifugio, e, a mia volta, offrì a me, tentando di immaginarlo, ispirazione].

\footnotetext{
4 Idem, "Reflective Biography", The Henry James Review Vol. 30 N. 3 (Fall 2009), p. 267.

5 Idem, "The Haunting of Lamb House", The Henry James Review Vol. 30 N. 3 (Fall 2009), p. 224.
} 
È la fine di dicembre 1895, nella Lamb House a Rye in Inghilterra. Henry sta bruciando delle lettere evocando Constance morta a Venezia un anno prima. Come morì? La rivedrà? E il fantasma di lei gli appare.

Ricordano insieme i giorni del lontano 1887, quando condivisero la villa BrichieriColombi a Bellosguardo sulle colline di Firenze: "We walked by the Arno that Spring and then through the streets of Florence [...] I was/You were Isabel Archer"6. ["Camminavamo lungo l'Arno quella Primavera e poi fra le strade di Firenze [... ] Io ero/Tu eri Isabel Archer”].

Rivivono il debutto di Guy Domville al St. James Theatre di Londra nel 1895, mentre appare anche un'attrice di quella produzione, Mrs. Edward Saker (1848-1912). Henry non è presente alla recita perché nascosto in un vicino teatro dove assiste invece al successo di An Ideal Husband di Oscar Wilde: "The crowd loved his cheap jokes, his cheap play. I was alone in hating it" . ["Il pubblico amava le sue battute scadenti, la sua commedia da due soldi. Ero solo io ad odiarla”]. Raggiunge il St. James Theatre solo alla fine dello spettacolo, dove, catapultato sul palco per ricevere gli applausi, viene invece insultato dal pubblico pagante che urla impietoso. Il coro intona "The worst play since time began! Shame, shame on the author, shame!". ["Il peggiore spettacolo dall'inizio dei tempi! Vergogna, vergogna all'autore, vergogna!"].

Guy Domville verrà sospeso e sostituito da The Importance of Being Earnest di Oscar Wilde, con stesso cast, attori e manager. Henry reagisce al fallimento preparandosi a scrivere i tre grandi romanzi, The Wings of The Dove, The Ambassadors and The Golden Bowl: "I take up my own old pen again - the pen of all my old unforgettable efforts and sacred struggles. To myself - today - I need say no more. Large and full and high the future still opens. It is now indeed that I may do the work of my life. And I will". ["Riprendo ancora in mano la mia vecchia penna - la penna di tutti i miei vecchi indimenticabili sforzi e sacre lotte. A me stesso - oggi - non ho bisogno di dire altro. Vasto, pieno e sommo si apre ancora il futuro. $\grave{E}$ certamente adesso che potrò realizzare l'opera della mia vita. E lo farò”].

Constance cerca di convincere Henry a dedicarsi esclusivamente alla propria arte, mettendolo in guardia dalle distrazioni che nel corso dell'opera prendono vita in tre differenti personaggi: Hammond, Oliver Wendell Holmes e Hendrik Christian Andersen. "I want his sexuality to be concealed, unspoken, with no private sexual moments shared with the reader". ["Voglio che la sua sessualità sia celata, non detta, priva di rapporti sessuali condivisi con il lettore"].

Malgrado le obiezioni del fantasma di Constance, "Henry James shouldn't waste his time with frivolous people"10, ["Henry James non dovrebbe perdere il suo tempo con gente frivola”], James accetta l'invito di Lord e Lady Wolseley (1843-1920) per un estenuante party al Royal Hospital di Dublino, dove viene preso in giro per le origini della sua famiglia irlandese emigrata in America dalla contea di Cavan, "The very end of the known world, filled with Irish at their worst, all filthy, all filled with superstition and vile poverty" ["Lestremità del mondo conosciuto, piena di irlandesi nelle loro peggiori condizioni, tutti

6 The Master, opera lirica, musica di Alberto Caruso, libretto di Colm Tóibín, scena 2.

7 Ibidem, scena 3.

8 H. James, The Notebooks of Henry James, ed. F. O. Matthiessen and K. B. Murdock, University of Chicago Press, Chicago and London 1981 [1947] p. 179.

9 C. Tóibín, "A More Elaborate Web", op. cit., p. 231.

10 The Master, opera lirica, op. cit., scena 5. 
indecenti, tutti intrisi di superstizione e ignobile povertà"] e per la sua immobilità nella sala da ballo, "I am not a dancer. I sit at my desk all day and move my pen". "'Io non sono un ballerino. Siedo alla mia scrivania tutto il giorno e muovo la mia penna”]. A notte fonda nella propria stanza riceve la visita del servitore Hammond - l'unico personaggio del romanzo inventato da Tóibín -, inviato dalla padrona di casa per tentarlo. Si intrattengono in una gentile conversazione notturna.

Nel frattempo, lo spettro di Oscar Wilde si ripresenta con la visita di un amico nel suo appartamento di Kensington. È lo scrittore Edmund Gosse (1849-1928), che gli racconta gli scabrosi sviluppi del processo ed arresto di Wilde, "Perversity, depravity and vice"11, ["Perversità, depravazione e vizio"], volendo insinuare addirittura un pericolo per lo stesso Henry, che elegantemente non accoglie: "All my dreams are here $[\ldots]$ only on paper with my pen”. ["Tutti i miei sogni sono qui [... ] solamente sulla pagina con la mia penna”].

Con Oliver Wendell Holmes Jr. (1841-1935), reduce dalla guerra civile, si trova invece a dover passare la notte a casa della sorella Alice (1848-1892), che ha preparato per loro un'unica stanza e un unico letto dove i due amici devono dividere i propri incubi, di guerra per Holmes e di pulsioni per Henry in dormiveglia: "Alone we dream, alone we find the images"12. ["Soli sogniamo, soli troviamo le immagini"].

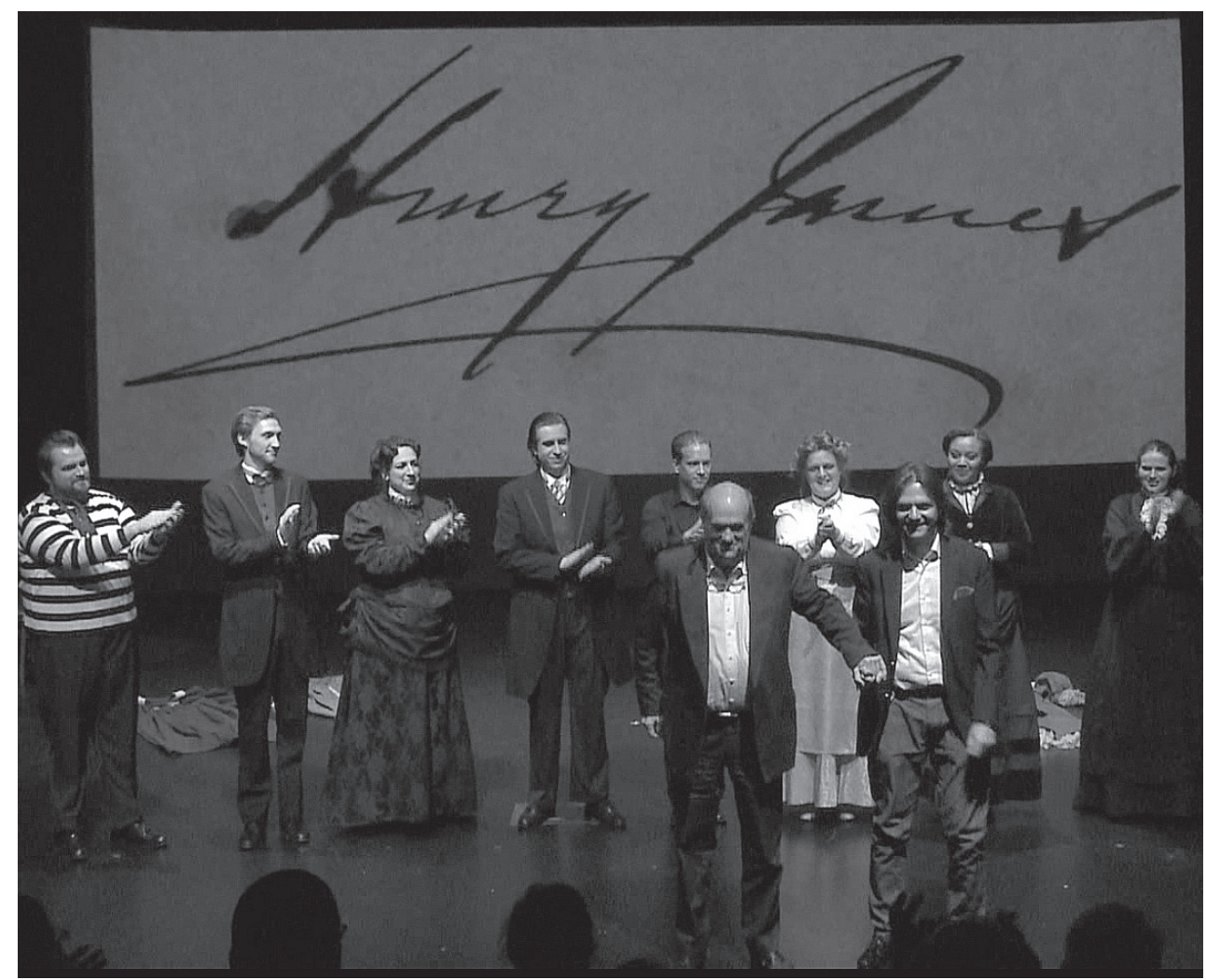

Colm Tóibín, Alberto Caruso, and the cast. From the author's private collection

\footnotetext{
11 Ibidem, scena 7.

12 Ibidem, scena 8.
} 
Infine il terzo e più complicato rapporto di amicizia, quello con Hendrik Christian Andersen (1872-1940), lo scultore conosciuto a Roma a casa di William Wetmore Story, il circolo degli artisti inglesi e americani residenti all'epoca nella capitale italiana. Il giovane Hendrik si presenta al Maestro lusingandolo: "I have read and love your books Roderick Hudson, and the sad girl Daisy Miller buried in the cemetery in Rome"13. ["Ho letto e amo i vostri libri Roderick Hudson, e la triste ragazza Daisy Miller sepolta nel cimitero di Roma”].

Portando Andersen con sé, Henry rende omaggio alla tomba di Constance, sepolta nel cimitero acattolico di Roma, all'ombra della Piramide Cestia, “That divine little Protestant Cemetery where Shelley and Keats lie buried”, ["Quel divino piccolo Cimitero Protestante dove Shelley e Keats giacciono sepolti”], come scrive Henry James in una lettera alla madre, e dove oggi riposa lo stesso Andersen. Poi si recano nello studio dello scultore, dove James resta frastornato dalle sue colossali statue: "His ambitions the size of the world. He wants to make a new city. His figures have no faces carved. All bottom and calf and belly and haunch!"14. ["Le sue ambizioni di dimensione mondiale. Vuole creare una nuova città. Le sue figure non hanno visi scolpiti. Solo sederi e polpacci e pance e cosce!”].

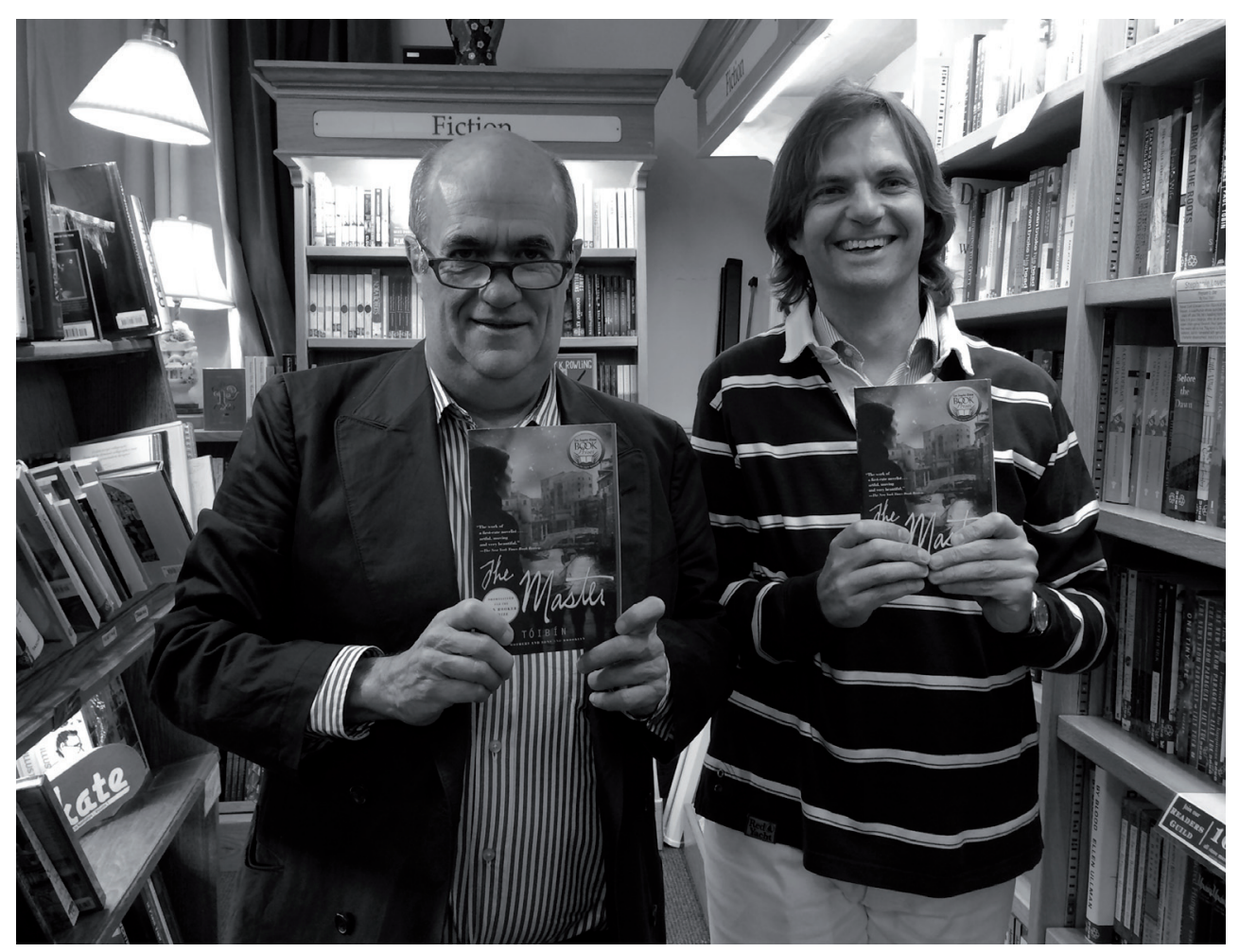

Colm Tóibín, Alberto Caruso. From the author’s private collection

\footnotetext{
13 Ibidem, scena 9.

14 Ibidem, scena 11.
} 
Dopo Roma, James si trova di nuovo in Inghiltera, con il fratello William (1842-1910), al capezzale della sorella morente Alice, che delirante lo prende in giro per la sua relazione con Constance: "It is like Chopin and George Sand"15. ["È come Chopin e George Sand"]. Henry mette a tacere l'insistente curiosità dei fratelli e risponde che il suo unico amore nella vita è la scrittura, "I match myself with words not love, until the words become my love. My life I dedicate to words". ["Io mi unisco alle parole, non all'amore, fino a quando le parole diventano il mio amore. La mia vita io la consacro alle parole”]. La devota governante Miss Loring fa addormentare Alice intonando una dolce berceuse.

Dalla sua casa di Rye, "La casa dei sogni di James", come la definisce Tóibín, James comincia un intenso rapporto epistolare con Andersen, fino a quando Constance riuscirà a cancellarlo dalla vita del Maestro. Henry è convinto adesso dell'opportunismo ambizioso del giovane scultore: "Let's forget his need for fame, the stone he ruins. Now that it is night I will delete his presence from my mind"16. " "Dimentichiamo il suo bisogno di fama, la pietra che rovina. Adesso che è notte cancellerò la sua presenza dalla mia mente"].

Quella stessa notte diventa, nella scena finale, il ricordo dell'ultima notte di Constance a Venezia, il 20 gennaio 1894. La scrittrice ricorda chiaramente la propria solitudine nell'attesa di Henry, "You promised that you'd come to stay"17, ["Promettesti che saresti venuto"], ma non ricorda come sia morta. Il suo gondoliere Tito appare nell'ombra. Henry e Tito le raccontano il suo suicidio: "From the window you jumped to death, your broken body on the stone". ["Dalla finestra saltasti alla morte, il tuo corpo infranto sulla pietra"].

Con la gondola, i due uomini escono in laguna portando gli abiti voluminosi di Constance con l'intenzione di tumularli in un "watery grave", ["una tomba d'acqua"], ma appena sommersi riemergono continuamente: "The dresses had risen to the top like strange creatures come from the deep. [...] They floated like they were alive". ["I vestiti affiorarono sulla superficie come strane creature emerse dal fondo. [... ] Galleggiarono come fossero vivi”].

È ancora notte, nella laguna di Venezia come nella casa dei sogni di Henry a Rye. Henry dà l'addio al "sweet ghost" ["dolce fantasma"] di Constance che ritorna nell'oscurità. Insieme invocano il reciproco riposo.

L'ultima sera a Boulder il nostro trio si separa geograficamente ma il lavoro in sinergia continuerà a distanza. Salutiamo il successo del workshop con l'Università e il cast: Kristyn Christman-McCarty, Max Hosmer, Rebecca Kidnie, Wei Wu, Charles Daniel, Adara Towler, James Held, Taylor Raven, Robert Spillman, Joshua Horsch, e la produzione: Leigh Holman, Patrick Mason, Malcolm Ulbrick, Ron Mueller, Andrew Metzroth, Tom Robbins, Linda Walters, Jeff Rusnak, Hally Albers, Gary McCrumb, Aimie Holdorf, Alex Klinger, Rojana Savoye, Chris Martin.

All'indomani della nostra Boulder, Colm Tóibín conquisterà Broadway con una nomination ai Tony Awards per il suo The Testament of Mary, e Hollywood con la trasposizione cinematografica del suo romanzo Brooklyn. Ron Daniels continuerà la sua intensa attività teatrale e operistica, anche con The Testament of Mary di Tóibín a Rio de Janeiro; e io debutterò in Italia, a Torino, con la ripresa della mia prima opera Il Piccolo Principe già eseguita in giapponese a Tokyo.

15 Ibidem, scena 12.

16 Ibidem, scena 14.

17 Ibidem, scena 15. 